\title{
COMPARISON OF LATE BLIGHT RESISTANCE AND YIELD OF POTATO VARIETIES
}

\author{
Terje Tähtjärv*,**, Aide Tsahkna*, and Sirje Tamm* \\ * Jõgeva Plant Breeding Institute, 1 J. Aamisepa Str., Jõgeva alevik, 48309, ESTONIA \\ ** Institute of Agricultural and Environmental Sciences, Estonian University of Life Sciences, 1 Kreutzwaldi Str., 51014 Tartu, ESTONIA \\ terje.tahtjarv@jpbi.ee, aide.tsahkna@jpbi.ee, sirje.tamm@jpbi.ee
}

Communicated by Isaak Rashal

\begin{abstract}
Growing more resistant potato varieties is one of the most effective strategies to control late blight, to protect potato yield and to prevent harming the environment. The main aim of our study was to identify potato varieties with higher resistance to late blight and which were high yielding in Estonian conditions and suitable for organic farming. During the three-year trial, twelve potato varieties were tested at the Jógeva Plant Breeding Institute (PBI) in 2010-2012. Foliage late blight (Phytophtora infestance (Mont) de Bary) and yield were estimated. First infection of late blight occurred in different times during the trial years. The three-year average infection level indicated that early varieties 'Arielle', 'Impala' and 'Princess' were more damaged than other varieties in the first estimation. Late varieties 'Ando', 'Anti', 'Juku' and 'Sarme' had higher late blight resistance. Their foliage damage remained less than $30 \%$ in the last estimation. The new medium variety 'Teele' had a lower infection rate than other medium varieties and did not significantly differ from late varieties. Based on these data, late varieties, early variety 'Maret' and medium variety 'Teele' can be considered suitable for organic farming. The new variety 'Teele' had the highest threeyear average tuber yield (52.8 t ha $\left.^{-1}\right)$. Varieties 'Impala', 'Princess' and 'Secura' had significantly lower yield. Yield loss of these varieties might have been caused by higher late blight infection during trial years.
\end{abstract}

Key words: potato variety, late blight resistance, yield.

\section{INTRODUCTION}

Potato, the third largest global food crop after wheat and rice, suffers from the devastating late blight disease, which causes 16\% loss of yield globally (Haverkort et al., 2009). Late blight, caused by the plant pathogen Phytophtora infestans (Mont.) de Bary, is one of the most devastating potato diseases worldwide. Two phenotypic expressions of host plant resistance to $P$. infestans have been described. The distinction between two types of resistance, qualitative (race-specific) and quantitative (field resistance), is controlled by major $R$ genes and minor genes. Factors controlling quantitative resistance to $P$. infestans have been found on almost every potato chromosome, confirming the truly polygenic nature of this trait (Gebhard and Valkonen, 2001). The most sustainable strategy to protect potato plants from late blight is to breed disease resistance $(R)$ genes into the cultivars (Hansen et al., 2005). Potato breeding is complicated because potato cultivars are highly heterozygous autotetraploid plants $(2 n=4 x=4 n)$, they suffer from acute inbreeding depression and introduced $R$ genes are quickly deflated by $P$. infestans (Fry, 2008). Also, quantitative resistance is thought to result in a more durable resistance un- der field conditions (Solomon-Blackburn et al., 2007; Fry, 2008). Late blight resistance breeding has been pretty much unsuccessful for more than 150 years (Müller and Black, 1952), and breeding for multigenic resistance, including field resistance, remains a major challenge (Rietman, 2012).

In northern areas, under favourable air temperature (15-20 ${ }^{\circ} \mathrm{C}$ ) and moist conditions, the pathogen can cause considerable yield loss (Runno-Paurson et al., 2013). More than $90 \%$ relative humidity in air creates the most suitable conditions for development of the sporangia of late blight, especially if the potato leaves stay moist at least three hours (Hooker, 1990).

Different strategies have been used at the Jõgeva Plant Breeding Institute to breed late blight resistant varieties. The Jõgeva Plant Breeding Institute has released varieties with efficient major gene-based late blight resistance, like 'Sulev' and 'Olev' in 1950s. The next strategy included pyramiding resistance genes using geographically distinct parents. Variety 'Sarme' $\left(R_{1} R_{2} R_{3} R_{4}\right)$ was obtained from a cross between 'Commandeur' $\left(R_{3}\right)$ (Holland) and M 987 $\left(R_{1} R_{2} R_{4}\right)$. Increases in pathotype complexity (Runno et al., $2009)$ and diversity created additional difficulties in potato 
breeding for late blight resistance. Only varieties with high levels of field resistance are able to avoid severe late blight epidemics. New sources of disease resistance were used to create more resistant varieties. Potato variety 'Anti' with high level of field resistance to late blight was originated from a multiple cross ((( Sol. demissum $x$ Sol. infundibuliforme $) \times$ (Vega') $\times$ (Unikat') $\times$ (Bellona') $\times$ (Super') and released in 1995. The last strategy has been to combine late blight resistance with earliness. Variety 'Maret' ('Vita' $\times$ 'Frila') is registered in Estonia since 2003 as an early variety. Non-specific late blight $r$ esistance of the variety 'Maret' is on the same level as that of most of the main crop varieties, but due to much earlier yield formation it is able to escape late blight development (Koppel and Tsahkna, 2003). Several of our varieties contain some wild Solanum species in their pedigree. For example, the newest variety 'Teele' includes Sol. andigenum, Sol. demissum, Sol. chiloense and Sol. vernei in its pedigree.

The main aim of the research was to compare the resistance to late blight of Estonian and EU potato varieties that are most commonly grown in Estonia. The necessity for the research was caused by the fact that late blight resistance in local conditions does not always occur according to that provided in the variety description.

\section{MATERIALS AND METHODS}

The trial to estimate late blight resistance and tuber yield of potato varieties was carried out at the Jõgeva Plant Breeding Institute in 2010-2012. The used experimental fields of the Jõgeva PBI were located on sandy loam Calcaric Luvisol soil (FAO/UNESCO classification). According to Soil Monitoring Bureau of Estonian Agricultural Research Centre the $\mathrm{pH}$ of trial field soils was in the range of 5.5-6.0, $\mathrm{K}$ $\left(\mathrm{mg} \mathrm{kg}^{-1}\right)$ fertiliser demands were medium and $\mathrm{P}\left(\mathrm{mg} \mathrm{kg}^{-1}\right)$ fertiliser demands were very low. The fields were deeply disced, cultivated and complete chlorine free mineral fertiliser (containing $80 \mathrm{~g} \mathrm{~kg}^{-1} \mathrm{~N}, 50 \mathrm{~g} \mathrm{~kg}^{-1} \mathrm{P}$ and $190 \mathrm{~g} \mathrm{~kg}^{-1} \mathrm{~K}$ ) by $650 \mathrm{~kg} \mathrm{ha}^{-1}$ was used locally in spring. Planting was conducted every year in the second decade of May. Chemical weed control was carried out with a mixture of the herbicides Sencor $\left(250 \mathrm{~g} \mathrm{ha}^{-1}\right)$ and Titus $\left(25 \mathrm{~g} \mathrm{ha}^{-1}\right)$. No chemical control for late blight was employed. During the growth period the plants were hilled three times and harrowed once. The trial was carried out in three replications.

Six Estonian potato varieties were used: early variety 'Maret', medium variety 'Teele' (developed in 2012), late varieties 'Anti', 'Ando', 'Sarme' and 'Juku'; four Dutch varieties 'Arielle' (early), 'Impala' (early), 'Fontane' (medium), 'Secura' (medium); one German variety 'Princess' (early), and one Danish variety 'Folva' (medium). These are the most commonly grown potato varieties in Estonia. One of the most important factors affecting late blight infection is weather condition during the vegetation period, especially temperature, precipitation and relative humidity. Data on weather conditions during the trial years is presented in Table 1 . The estimation of late blight was carried out three times and the first estimation depended on the beginning of the infection. The estimations of late blight were carried out on 10 and 17 August and 1 September in 2010; on 15, 23 and 28 August in 2011; and on 13, 21 and 27 August in 2012. Late blight was estimated visually as \% of infected leaf surface. The tuber crop was weighed in autumn. Spatial distributions were analysed using NNA (Nearest Neighbour Analysis) with the AGROBASE 20 computer package. To determine significant differences between traits, the least significant differences $\left(\mathrm{LSD}_{05}\right)$ were calculated.

\section{RESULTS}

In the end of July 2010 (29-30), when conditions were very favourable for late blight (low temperature, precipitation, high relative humidity), the first late blight infection was observed in the early varieties. Additionally, favourable conditions for further infection development occurred in the first decade of August (Table 1). In 2011, the first infection in the early varieties was observed in the end of July (31), but infection development had stopped in the beginning of August (1-6), due to the hot and dry weather. Late blight infection development continued in the second decade of Au-

Table 1

WEATHER CONDITIONS DURING THE POTATO LATE BLIGHT RESISTANCE TESTING PERIOD

\begin{tabular}{|c|c|c|c|c|c|c|c|c|c|c|}
\hline \multirow[t]{2}{*}{ Month } & \multirow[t]{2}{*}{ Decade } & \multicolumn{3}{|c|}{ Average air temperature, ${ }^{\circ} \mathrm{C}^{*}$} & \multicolumn{3}{|c|}{ Precipitation sum, mm* } & \multicolumn{3}{|c|}{$\begin{array}{c}\text { Average relative } \\
\text { humidity, \%* }\end{array}$} \\
\hline & & 2010 & 2011 & 2012 & 2010 & 2011 & 2012 & 2010 & 2011 & 2012 \\
\hline \multirow[t]{3}{*}{ June } & I & 13.2 & 19.8 & 11.2 & 28 & 0 & 29 & 72 & 61 & 73 \\
\hline & II & 13.7 & 16.0 & 15.1 & 35 & 28 & 39 & 76 & 76 & 74 \\
\hline & III & 16.0 & 16.5 & 13.8 & 25 & 10 & 42 & 75 & 75 & 77 \\
\hline \multirow[t]{3}{*}{ July } & I & 20.1 & 20.8 & 19.3 & 31 & 14 & 16 & 73 & 75 & 75 \\
\hline & II & 23.2 & 19.3 & 15.5 & 3 & 11 & 58 & 71 & 76 & 81 \\
\hline & III & 22.8 & 21.5 & 19.1 & 10 & 9 & 11 & 71 & 77 & 75 \\
\hline \multirow[t]{3}{*}{ August } & I & 21.2 & 16.4 & 16.0 & 19 & 14 & 22 & 76 & 73 & 80 \\
\hline & II & 19.6 & 16.2 & 14.7 & 26 & 47 & 76 & 77 & 86 & 83 \\
\hline & III & 13.9 & 16.3 & 13.5 & 46 & 13 & 32 & 84 & 62 & 87 \\
\hline
\end{tabular}

* According to Jõgeva PBI weather station 
gust, when weather was cool and relative humidity was very high (Table 1). Hot and dry weather in the end of July and in the beginning of August of 2012 delayed the start of late blight infection. The first late blight infection was observed in the early varieties on 6 August. Rapid development of the disease began in the second decade of August, when weather turned cooler and relative humidity was higher (Table 1). The first late blight infection was minimal and observed only on the early varieties. Therefore, our experimental data was based on subsequent estimations when also medium and late varieties had been infected. Blight development was very fast for varieties 'Maret' and 'Arielle', fast for 'Folva', 'Ando', 'Sarme' and 'Juku', and slow for 'Secura', 'Fontane', 'Teele', 'Anti', 'Impala' and 'Princess'. Figures 1, 2, and 3 provide data on late blight infection development and scale of infection in the years 2010, 2011 and 2012, along with the results of three follow-up late blight estimations and the three-year average. Figure 4 shows the average infection intensity in the first, second and thirds estimations in the trial years. As potato late blight can

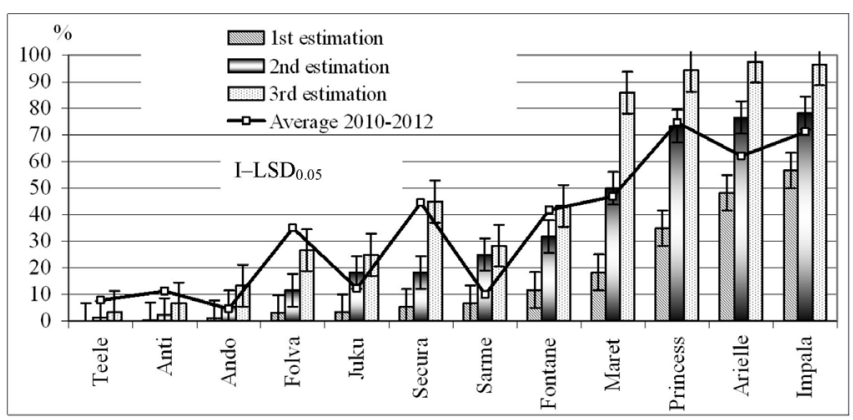

Fig. 1. Late blight estimations in 2010. LSD $_{0.05}$ for average $2010-2012=$ $12.78 \%$.

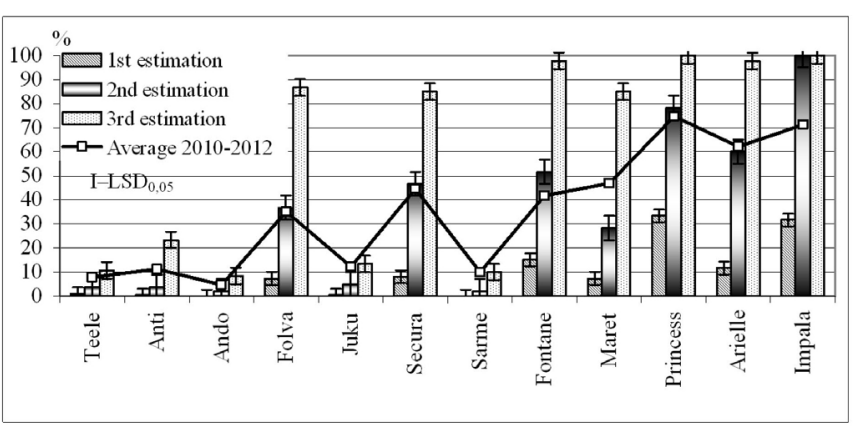

Fig. 2. Late blight estimation in 2011. LSD $_{0.05}$ for average $2010-2012=$ $12.78 \%$.

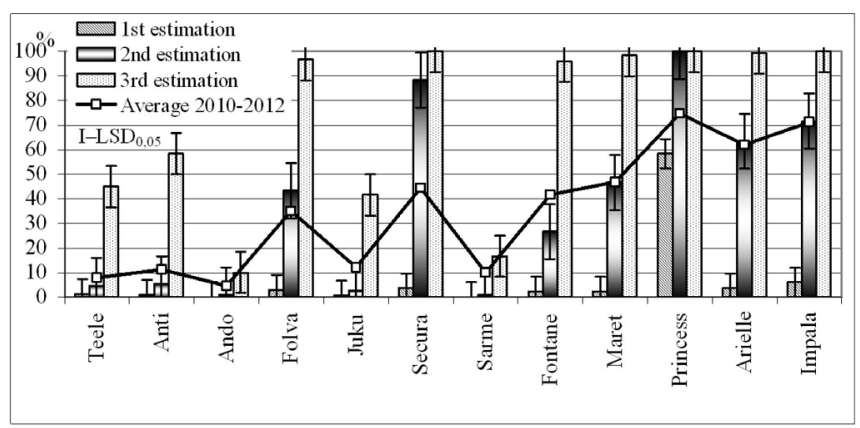

Fig. 3. Late blight estimation in 2012. LSD $_{0.05}$ for average $2010-2012=$ $12.78 \%$. cause extensive damage to potato foliage, it is definitely a factor that affects tuber yield. Figure 5 shows the tuber yield in the trial years, in comparison with the three-year average tuber yield.

\section{DISCUSSION}

Late blight resistance. According to the literature, early varieties are much more susceptible to late blight than late varieties (Tan et al., 2010). During the trial years, the beginning of infection of late blight differed between years. It occurred latest in 2012, probably due to below average air temperature in the second half of the vegetation period (Table 1).

First estimation.. Of the early varieties used in the trial, 'Impala' (57\%) and 'Arielle' (48\%) had the highest infection in 2010 ( $\mathrm{LSD}_{05}$ 13.4\%) (Fig. 1). In 2011, the infection of these varieties was not particularly high (32\% and 12\%, respectively) (Fig. 2), and in 2012 it was only 6\% and 4\%, respectively (Fig. 3). In contrast, the the infection intensity for the early variety 'Princess' at first estimation was $29 \%$ in 2010, 33\% in 2011 and as high as 58\% in 2012 (Figs. 1, 2,3 ). This might be explained by the occurrence of different pathotypes of late blight during the trial years and also by the absence of resistance to certain pathotype (Runno et al 2010). Of the medium varieties, the least infected in the first estimation was variety 'Teele' and the most infected variety

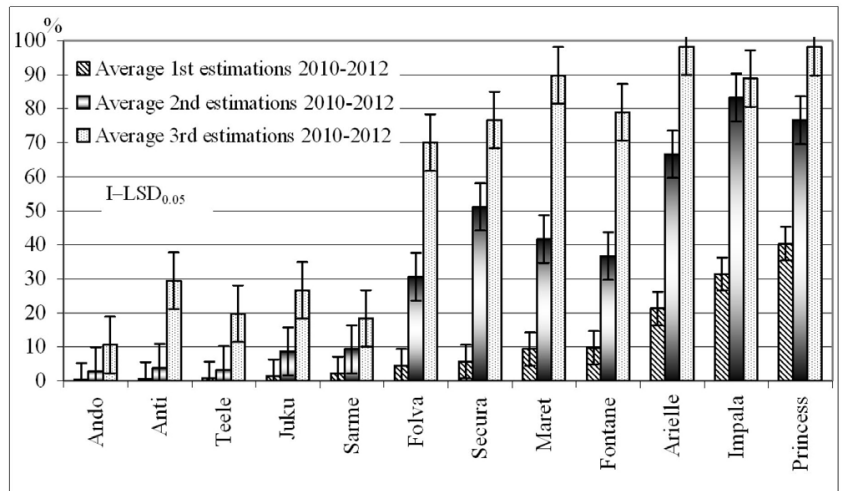

Fig. 4. Averages of 1 st, 2 nd and 3rd estimations of late blight infection in 2010-2012.

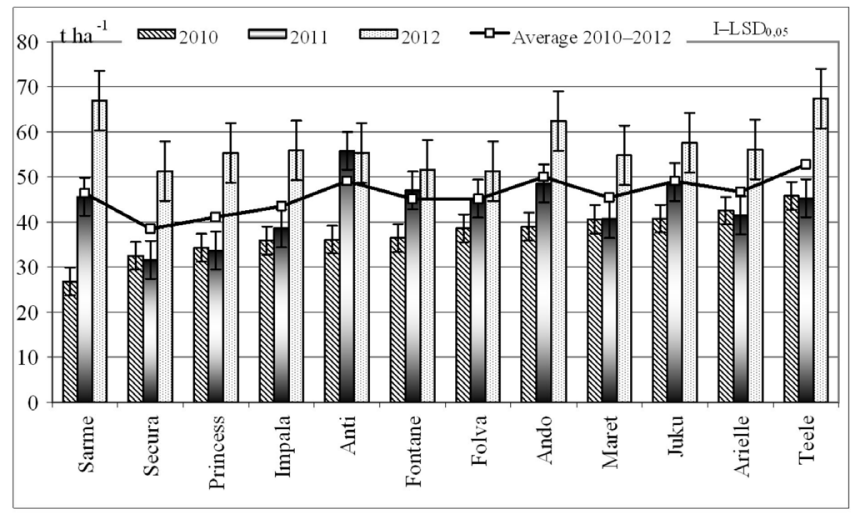

Fig. 5. Yield of tubers in 2010-2012. LSD $_{0.05}$ for average 2010-2012 = 9.3 $\mathrm{t} \mathrm{ha}^{-1}$. 
'Fontane' in all-trial years. According to the literature (Tan et al., 2010), there is a positive correlation between late maturity and resistance. Thus, the late varieties should have higher resistance to late blight. Of the four late varieties used in the trial, 'Ando' and 'Anti' were the least infected and 'Juku' and 'Sarme' were slightly infected in the first estimation in all trial years.

The second estimation. Of the early varieties, 'Maret' was the least infected in all trial years: $50 \%$ in $2010\left(\mathrm{LSD}_{05}\right.$ $12.3 \%), 28 \%$ in $2011\left(\mathrm{LSD}_{05} 10.0 \%\right)$ and $47 \%$ in 2012 $\left(\mathrm{LSD}_{05} 22.5 \%\right)$ (Fig. 1, 2, 3). At time of the second estimation, 'Impala' and 'Princess' had the highest infection of late blight in all three trial years: 'Impala' at a level of $100 \%$ in 2011 and 'Princess' in 2012. Of the medium varieties, the new variety 'Teele' was the least infected in all trial years. The highest level of infection occurred on varieties 'Fontane' (32\% in 2010 and 52\% in 2011) and 'Secura' ( $88 \%$ in 2012). Among the late varieties, infection had not significantly spread by the time of second estimation, except in 2010 when the infection had spread up to $18 \%$ on variety 'Juku' and to $25 \%$ on variety 'Sarme'.

The third estimation. Of the early varieties, leaf damage caused by late blight was least severe on 'Impala' (96\%) and the highest on 'Arielle' (98\%) in 2010 ( $\left.\mathrm{LSD}_{05} 15.8 \%\right)$ (Fig. 1). In 2011, 85\% of foliage on variety 'Maret' was destroyed, and $100 \%$ of that of 'Impala' and 'Arielle' (LSD $_{05}$ 6.8\%) (Fig. 2). In 2012, late blight infection occurred later and developed significantly faster. By the time of the third estimation, the foliage of early varieties was destroyed by 98-100\% ( $\left.\mathrm{LSD}_{05} 16.9 \%\right)$ (Fig. 3). It was obvious that the new variety 'Teele' has relatively high field resistance to late blight, as by the third estimation only 3\% (2010), 10\% (2011) and $45 \%$ (2012) of its foliage was infected. The highest level of infection occurred on medium varieties in 2011 and $2012-85 \%$ (2011) and 100\% (2012) on 'Secura', and 98\% (2011) on 'Fontane'. At the time of the third estimation, the most resistant late varieties were 'Anti' (2010) and 'Ando' (2011 and 2012).

This discussion provides a clear picture of late blight infection throughout different trial years. The three-year average results showed that at the time of the first estimation the most resistant variety to late blight was 'Ando' (Fig. 4). 'Maret', 'Teele', 'Folva', 'Secura', 'Anti', 'Juku' and 'Sarme' had similar resistance to late blight $\left(\mathrm{LSD}_{05} 9.7 \%\right)$. The varieties 'Arielle', 'Impala', 'Princess' and 'Fontane' were significantly more susceptible to late blight infection. According to the second estimation, the most resistant variety to late blight infection was 'Ando' and the resistance of varieties 'Teele', 'Anti', 'Juku' and 'Sarme' did not differ significantly ( $\left.\mathrm{LSD}_{05} 13.9 \%\right)$. All other varieties used in the trial showed significantly higher susceptibility to late blight infection. We conclude that varieties with lower late blight infection have higher resistance against late blight. At the time of the third estimation, the variety 'Ando' was the most resistant to late blight (Tsahkna et al., 2009) and varieties 'Teele', 'Juku' and 'Sarme' did not differ from it significantly $\left(\mathrm{LSD}_{05} 16.7 \%\right)$.
Tuber yield. Of the varieties used in the trial, 'Teele' had the highest tuber yield (45.8 $\mathrm{t} \mathrm{ha}^{-1}$ ) in 2010 (Fig. 5). Tuber yields of varieties 'Maret', 'Arielle' and 'Juku' did not differ significantly $\left(\operatorname{LSD}_{05} 6.1 \mathrm{t} \mathrm{ha}^{-1}\right)$. All other varieties had significantly lower tuber yield. In 2011, variety 'Anti' had the biggest tuber yield $\left(55.8 \mathrm{t} \mathrm{ha}^{-1}\right)$ and tuber yields of varieties 'Juku' and 'Fontane' did not differ significantly $\left(\mathrm{LSD}_{05} 8.4 \mathrm{t} \mathrm{ha}^{-1}\right)$. The tuber yield of 'Princess', 'Impala' and 'Secura' was lower, as these were more susceptible varieties to late blight and the pathogen had spread quickly. In 2012, variety 'Teele' had the highest tuber yield (67.4 t $\left.\mathrm{ha}^{-1}\right)$, and tuber yields of varieties 'Fontane', 'Folva' and 'Secura' did not differ from it significantly ${\left(\mathrm{LSD}_{05}\right.} 13.3 \mathrm{t}$ $\mathrm{ha}^{-1}$ ). Compared to the other two trial years, late blight infection occurred later in 2012, and thus the early varieties 'Maret', 'Arielle', 'Impala' and 'Princess' had higher tuber yield. Tuber yields of late and more resistant varieties to late blight were significantly similar to the tuber yield of medium variety 'Teele' (55-66 $\left.\mathrm{t} \mathrm{ha}^{-1}\right)$. Variety 'Teele' had the highest three-year average tuber yield $\left(52.8 \mathrm{t} \mathrm{ha}^{-1}\right)$. Varieties 'Impala', 'Princess' and 'Secura' had significantly lower tuber yield, which was probably mainly caused by their lower field resistance to late blight infection.

The beginning of late blight infection occurred later in 2012. The first varieties to become infected were the early varieties 'Arielle', 'Impala' and 'Princess'. The most resistant early variety was 'Maret'. Attention could be drawn to the slow development of late blight on 'Maret', which enabled higher tuber yield. Of the medium varieties, 'Teele' was infected the least and significantly similar resistance to late blight occurred on late varieties 'Ando', 'Anti', 'Sarme' and 'Juku'. 'Teele' also showed slow development of the infection, similar as in the late varieties.

Varieties 'Maret', 'Teele', 'Ando', 'Anti', 'Sarme' and 'Juku' are more late blight resistant and can be recommended for organic farming (Tsahkna and Tähtjärv, 2009).

\section{ACKNOWLEDGEMENTS}

These studies were supported by the European Social Fund Doctoral Studies and Internationalisation Programme DoRa. Programme DoRa is carried out by the Archimedes Foundation.

The Estonian Foundation grants no 9432 and 9450; Target Financing SF170057s09 and project RESIST 3.2.0701.110003 supported the study.

\section{REFERENCES}

Fry, W. E. (2008). Phytophthora infestans: The plant (and R gene) destroyer. Mol. Plant Pathol., 9, 385-402.

Gebhardt, C., Valkonen, J. P. T. (2001). Organization of genes controlling disease resistance in the potato genome. Annu. Rew. Phytopathol., 39, 79-102.

Hansen, J. G., Koppel, M., Valskyte, A., Turka, I., Kapsa, J. (2005). Evaluation of foliar resistance in potato to Phytophthora infestans based on an international field trial network. Plant Pathol., 49, 11-22. 
Haverkort, A., Struik, P., Visser, R., Jacobsen, E. (2009). Applied biotechnology to combat late blight in potato caused by Phytophthora infestans. Potato Res., 52, 249-264.

Hooker, W. J., (1990). Compendium of Potato Diseases. APS Press. 125 pp.

Koppel, M., Tsahkna, A. (2003). Breeding of potato varieties for quality and disease resistance at Jõgeva Plant Breeding Institute. Материаль Международный юбилейной научно-практической конференции, посвященной 75-летию Института картофелеводства Национальной академии наук Беларуси, 7-10 июля 2003 г. Научные труды, часть II (рр. 70-76). Самохваловичи: РУП Институт картофелеводства НАН Беларуси.

Müller, K. O., Black, W. (1952). Potato breeding for resistance to blight and virus diseases during the last hundred years. Z. Pflanzenzucht., 31, 305-318.

Runno-Paurson, E., Fry, W. E., Myers, K. L., Koppel, M., Mänd, M. (2009). Characterisation of Phytophtora infestans isolates collected from potato in Estonia during 2002-2003. Eur. J. Plant Phatol., 124, 565-575.

Runno-Paurson, E., Fry, Remmel, T., Mänd, M., W. E., Myers, K. L. (2010). Phenotypic and genotypic characterisation of Estonian isolates of Phytophtora infestans in 2004-2007. Eur. J. Plant Phatol., 92 (2), 375-384.
Rietman, H., Bijsterbosch, G., Cano, L. M., Lee, H-R., Vossen, J. H., Jacobsen, E., Visser, R. G. F., Kamoun, S., Vleeshouwers, V. G. A. A. (2012). Qualitative and quantitative Late blight resistance in potato cultivar Sarpo Mira is determined by the perception of five distinct RXLR effectors. MPMI, 25 (7), 910-919.

Runno-Paurson, E., Williams, I. H., Metspalu, L., Kaart, T., Mänd, M. (2013). Current potato varieties are too susceptible to late blight to be grown without chemical control under North-East European conditions. Acta Agr. Scand. Section B. Soil Plant Sci., 63, 80-88.

Solomon-Blackburn, R. M., Stewart, H. E., Bradshaw, J. E. (2007) Distinguishing major-gene from field resistance to late blight (Phytophthora infestans) of potato (Solanum tuberosum) and selecting for high levels of field resistance. Theor. Appl. Genet., 115, 141-149.

Tan, M. Y. A., Hutten, R. C. B., Visser, R. G. F., van Eck, M. J. (2010). The effect of pyramiding Phytophthora infestans resistance genes $R_{P i-m c d l}$ and $R_{P i-b e r}$ in potato. Theor. Appl. Genet., 121, 117-112.

Tsahkna, A., Koppel, M., Tähtjärv, T. (2009). Breeding of potato varieties at the Jõgeva Plant Breeding Institute. В кн.: Использование мировых генетических ресурсов ВИР в создании сортов картофеля нового поколения (с. 209-214). Санкт-Петербург.

Tsahkna, A., Tähtjärv, T. (2009). Results of organic farming trial of potato in 2009. Agronomy, 126-131 (in Estonian).

Received 14 March 2013

\section{KARTUPEḶU ŠḲIRN̦U IZTURĪBAS PRET LAKSTU PUVI UN RAŽAS SALĪDZINĀJUMS}

Kartupel̦u šķirṇu, kas ir izturīgas pret slimībām, audzēšana ir viena no efektīvākajām stratēǵijām, lai pasargātu kartupeḷu ražu un nenodarītu kaitējumu videi. Viens no pētījuma mērḳiem bija noskaidrot ražīgas kartupeļu šķirnes ar labu izturību pret lakstu puvi, audzējot Igaunijas audzēšans apstākḷos, kā arī piemērotas bioloǵiskajai saimniekošanai. Trīs gadu laikā 12 kartupeḷu škirnes tika pārbaudītas Jegevas selekcijas institūtā (2010-2012). Tika izvērtēti lakstu puves bojājumi uz lapām un ražas lielums. Vidēji trīs gados pirmajā lakstu puves pārbaudes reizēs konstatēts, ka agrās šķirnes 'Arielle', 'Impala' and 'Princess' bija vairāk bojātas kā citas šķirnes. Vēlās šķirnes 'Ando', 'Anti', 'Juku' un 'Sarme' bija salīdzinoši izturīgākas pret lakstu puvi. Lakstu bojājumu apjoms šìm škirnēm bija 30\% apjomā arī pēdējās pārbaudes reizēs. Jaunajai vidēji agrai kartupeḷu šķirnei 'Teele' bija zemāks bojājumu apjoms nekā citām vidēji agrajām šķirnēm, tas būtiski neatšḳīrās no vēlo šḳirṇu vērtējuma. Pamatojoties uz šiem vērtējumiem, vēlās škirnes, agrā šḳirne 'Maret' un vidēji agrā šḳirne 'Teele' ir piemērotas bioloǵiskajai lauksaimniecībai. Jaunajai šķirnei ‘Teele' vidēji trīs gados bija augstākā raža (52.8 t ha $\left.{ }^{-1}\right)$. Škiinnēm 'Impala', 'Princess' un 'Secura' bija būtiski zemākas ražas. Ražas samazinājumu varēja izraisīt augstāka lakstu puves infekcijas pakāpe izmēǵinājuma gados. 